\title{
Rapid methods to detect organic mercury and total selenium in biological samples
}

\author{
Dong-Ha Nam, Niladri Basu
}

\begin{abstract}
Background: Organic mercury $(\mathrm{Hg})$ is a global pollutant of concern and selenium is believed to afford protection against mercury risk though few approaches exist to rapidly assess both chemicals in biological samples. Here, micro-scale and rapid methods to detect organic mercury $(<1.5 \mathrm{ml}$ total sample volume, $<1.5$ hour $)$ and total selenium ( $\mathrm{Se}$; $<3.0 \mathrm{ml}$ total volume, $<3$ hour) from a range of biological samples (10-50 mg) are described.

Results: For organic Hg, samples are digested using Tris- $\mathrm{HCl}$ buffer (with sequential additions of protease, $\mathrm{NaOH}$, cysteine, $\mathrm{CuSO}_{4}$, acidic $\mathrm{NaBr}$ ) followed by extraction with toluene and $\mathrm{Na}_{2} \mathrm{~S}_{2} \mathrm{O}_{3}$. The final product is analyzed via commercially available direct/total mercury analyzers. For $\mathrm{Se}$, a fluorometric assay has been developed for microplate readers that involves digestion $\left(\mathrm{HNO}_{3}-\mathrm{HClO}_{4}\right.$ and $\left.\mathrm{HCl}\right)$, conjugation (2,3-diaminonaphthalene), and cyclohexane extraction. Recovery of organic $\mathrm{Hg}$ (86-107\%) and Se (85-121\%) were determined through use of Standard Reference Materials and lemon shark kidney tissues.

Conclusions: The approaches outlined provide an easy, rapid, reproducible, and cost-effective platform for monitoring organic $\mathrm{Hg}$ and total Se in biological samples. Owing to the importance of organic $\mathrm{Hg}$ and $\mathrm{Se}$ in the pathophysiology of $\mathrm{Hg}$, integration of such methods into established research monitoring efforts (that largely focus on screening total $\mathrm{Hg}$ only) will help increase understanding of Hg's true risks.
\end{abstract}

\section{Background}

Mercury ( $\mathrm{Hg})$ is a ubiquitous heavy metal that is neurotoxic to humans and wildlife [1]. It is ranked as a top three priority pollutant by the U.S. EPA's CERCLA program [2]. In the U.S., more than $50 \%$ of water bodies are under fish consumption advisories largely due to $\mathrm{Hg}$ contamination [3]. In addition, Hg levels in the tissues of most fish-eating wildlife are within 10-fold of levels known to cause overt damage [4,5]. Mercury's fate and toxicity depends upon its chemical speciation. In particular, organic $\mathrm{Hg}$ (generally found as methyl $\mathrm{Hg}, \mathrm{MeHg}$ ) is of health concern since it penetrates lipid bilayers, biomagnifies through aquatic food chains, and about $95 \%$ of the ingested dose is absorbed into the blood stream [1]. Methyl $\mathrm{Hg}$ can also cross the blood brain barrier by conjugating with L-cysteine and exploiting the methionine-uptake pathway [6]. As $\mathrm{Hg}$ has a high affinity for protein thiols, multiple neural components are vulnerable to its toxic action [7].

\footnotetext{
* Correspondence: niladri@umich.edu

Department of Environmental Health Sciences, University of Michigan School of Public Health, Ann Arbor, Michigan 48109, USA
}

In an effort to assess $\mathrm{Hg}$ concentrations in biological samples, various analytical schemes are used [8-10]. Mercury strongly absorbs light at $253.7 \mathrm{~nm}$ and total $\mathrm{Hg}$ can be quantified via established spectroscopic methods. Recently, commercial vendors (e.g., Milestone Inc., BrooksRand, Perkin Elmer) have provided direct mercury analyzers to the market which permit rapid and straightforward analysis of total $\mathrm{Hg}$. However, the detection of organic $\mathrm{Hg}$ is still hindered by sample treatments steps that are time consuming, wet chemistry digestions that generate ample chemical waste, and/or need for complex instrumentation. One common method to assess organic $\mathrm{Hg}$ involves pretreatment of sample with acid followed by alkaline digestion, and then extraction with an organic solvent (benzene or toluene) and finally back-extraction into an aqueous solution using cysteine or thiosulphate [4,10-12]. Organic $\mathrm{Hg}$ compounds may be quantified on the basis of separation techniques (e.g., GC, HPLC) with a sensitive detector (e.g., ECD, CV-AAS, ICP-MS).

Selenium (Se) is an essential micronutrient. It is postulated that the presence of Se within cells may mitigate 
$\mathrm{Hg}$ toxicity by forming an inert crystalline $\mathrm{Hg}$-Se complex $[13,14]$. Further, strict $\mathrm{Hg}$-Se molar ratios of $1: 1$ have been observed in biological tissues from several organisms [15], though few $\mathrm{Hg}$ monitoring studies co-report on Se levels. The essential role of Se in physiology has encouraged the development of analytical methods for its quantification at trace levels. Among available techniques, fluorescence-based methods are considered to be easier and more cost-effective than conventional spectroscopic techniques (e.g., ICP-MS, GFAAS or HGAAS) [16] though few have outlined in detail key methodological considerations for the assessment of total Se in biological samples [17-19].

Owing to the need to determine both organic $\mathrm{Hg}$ and total Se in biological samples, there is a need to develop and apply of fast and reliable analytical methods. Here we detail a series of methods that may be used to simply and rapidly detect organic $\mathrm{Hg}(<1.5 \mathrm{ml}$ total sample volume, $<1.5$ hour $)$ and total Se $(<3.0 \mathrm{ml}$ total volume, $<3$ hour) in a range of biological samples.

\section{Experimental}

Figure 1 provides a graphical schematic of the procedure to extract and detect organic $\mathrm{Hg}$. About 10 to $50 \mathrm{mg}$ of

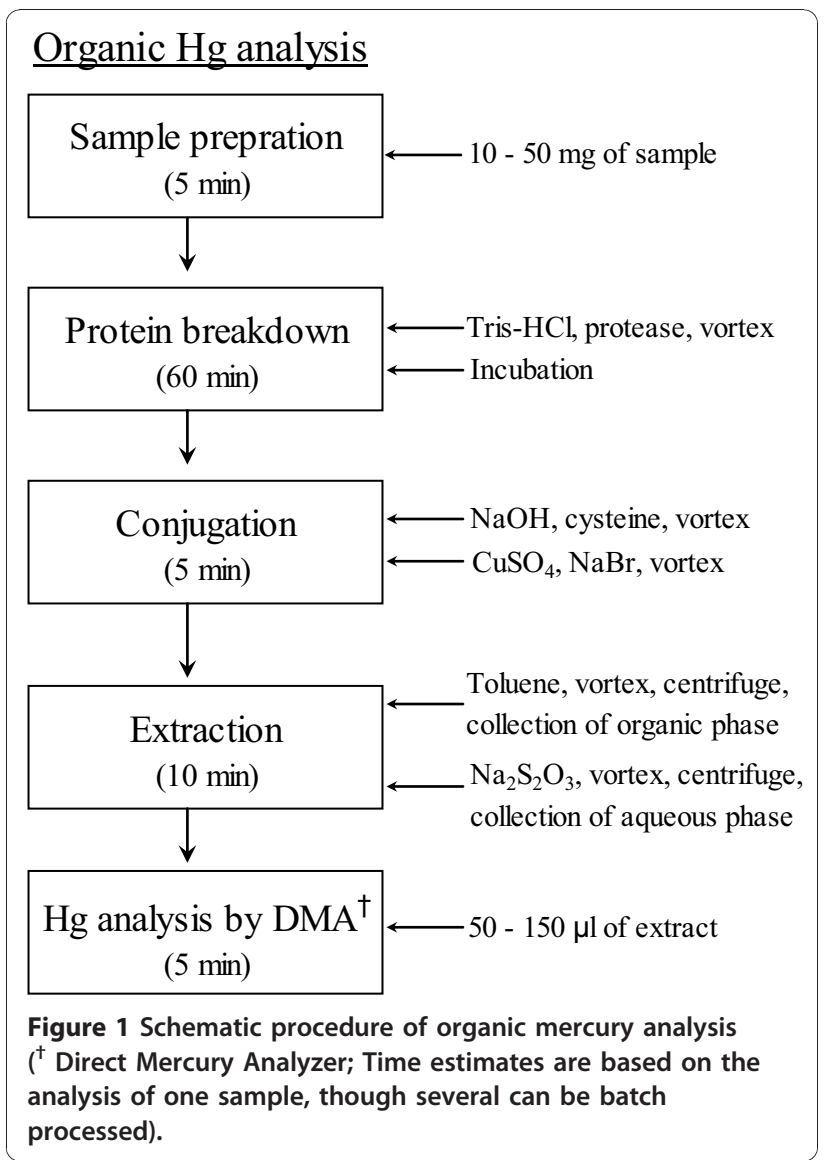

Standard Reference Materials (DOLT-3: dogfish liver, TORT-2: lobster hepatopancreas; both from the National Research Council of Canada, NIST 1566b: oyster tissue from National Institute of Standards and Technology, USA) was homogenized in $50 \mathrm{mM}$ Tris$\mathrm{HCl}$ buffer ( $\mathrm{pH} 8.5$ ) containing protease (Subtilisin A, $99 \% ; 100 \mu \mathrm{g})$, and next incubated at $50^{\circ} \mathrm{C}$ for $1 \mathrm{hr}$. Following this digestion step, $\mathrm{NaOH}(40 \% ; 125 \mu \mathrm{L})$, cysteine $(1 \% ; 50 \mu \mathrm{L}), \mathrm{CuSO}_{4}(0.5 \mathrm{M} ; 50 \mu \mathrm{L})$, acidic $\mathrm{NaBr}$ $(3.1 \% ; 500 \mu \mathrm{L})$, and toluene $(500 \mu \mathrm{L})$ were sequentially added to the digest and vortexed. Following centrifugation at 13,000 g for 5 minutes at room temperature, the top toluene layer was transferred to a test tube and mixed twice (60-80\% of toluene) with $\mathrm{Na}_{2} \mathrm{~S}_{2} \mathrm{O}_{3}(5 \mathrm{mM}$; $150 \mu \mathrm{L}$ ) to permit back-extraction of organic $\mathrm{Hg}$ into an aqueous phase. The aqueous phase was re-centrifuged $(13,000 \mathrm{~g}$ for 2 minutes) and then placed into another test tube (1.5 mL tube) for organic $\mathrm{Hg}$ analysis. The final extracts, once obtained, can be analyzed for $\mathrm{Hg}$ content within a few days. All samples (SRMs for total $\mathrm{Hg}$, extracts for organic $\mathrm{Hg}$ ) were directly analyzed by a DMA-80 (DMA-80 Milestone, Inc., Shelton, Connecticut, USA) as we have previously outlined elsewhere $[20,21]$. Briefly, the direct mercury analyzer liberates mercury by introducing samples into a controlled heated environment. Nickel and quartz boats are used to introduce solid and liquid samples, respectively, into the machine's autosampler. The autosampler delivers the sampling boats into a quartz catalytic tube, where it is dried and then thermally decomposed in a continuous flow of ultra pure oxygen. Combustion products are carried off and further decomposed in a hot catalyst bed. The remaining decomposition products are carried by oxygen to a gold amalgamator that selectively traps mercury vapour. After the system is flushed with oxygen to remove any remaining decomposition products, the amalgamator is rapidly heated to release the mercury vapour from the gold trap. Then, flowing oxygen carries the mercury vapour through absorbance cells positioned in the light path of a single wavelength atomic absorption spectrophotometer. Absorbance is measured at $253.7 \mathrm{~nm}$ as a function of mercury concentration. This method is endorsed by the U.S. Environmental Protection Agency (EPA Method 7473). Here, the detection limit for the direct $\mathrm{Hg}$ analyzer was $0.020 \mathrm{ng}$ and ranged from 0.010 to $0.029 \mathrm{ng}$. Total and organic Hg concentrations are expressed as $\mu \mathrm{g} / \mathrm{g}$ (ppm) dry weight.

A simplified microplate-based fluorometric assay (total volume $<3 \mathrm{ml}$ ) for biological samples has been developed, based on the tube-based method of Sheehan and Gao [18] developed for urine and plasma. The method involves sample digestion $\left(\mathrm{HNO}_{3}-\mathrm{HClO}_{4}\right.$ and $\left.\mathrm{HCl}\right)$, conjugation as a piazselenol (2,3-diaminonaphthalene, DAN), and cyclohexane extraction (Figure 2). Approximately 10 to $50 \mathrm{mg}$ 


\section{$\underline{\text { Total Se analysis }}$}

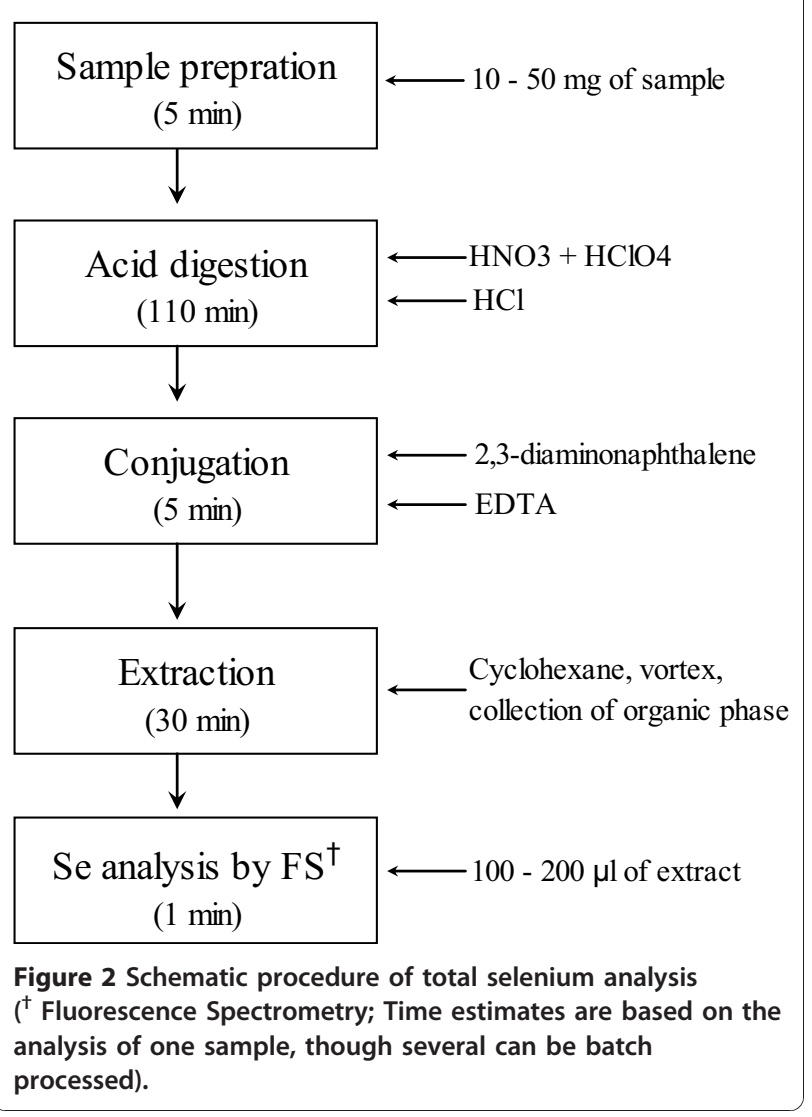

of SRMs (DOLT-3, TORT-2, NIST 1568a: rice flour, NIST 1577b: bovine liver, NIST 1515: apple leaves, selenite and selenate stock standard solution) and lemon shark (Negaprion brevirostris) samples were digested in the presence of $400 \mu \mathrm{L}$ of $\mathrm{HNO}_{3}(70 \%)$ and $100 \mu \mathrm{L} \mathrm{HClO}_{4}(40 \%)$ for $80 \mathrm{~min}$ at $195^{\circ} \mathrm{C}$, followed by the addition of $500 \mu \mathrm{L}$ of $\mathrm{HCl}$ for $30 \mathrm{~min}$ at $150^{\circ} \mathrm{C}$ in a borosilicate tube. These acid digestions facilitate the oxidation of all forms of Se (particularly selenide and selenate) into selenite (selenous acid). To the digest, $10 \mathrm{mM}$ of EDTA with sequential additions of $6.3 \mathrm{mM}$ of DAN in $0.1 \mathrm{M} \mathrm{HCl}(500 \mu \mathrm{L})$ and $1 \mathrm{~mL}$ of cyclohexane was added to form a fluorescent complex as a 4,7-dichloro-5,6-benzopiazselenol $\left(\mathrm{Cl}_{2}\right.$-Se-DAN complex) in an organic phase. Though endogenous metals present in working solutions may interfere with DAN, the interference may be masked by the addition of $10 \mathrm{mM}$ of EDTA, which we tested here $(250 \mu \mathrm{L}$; tested ranged from 1 to $100 \mathrm{mM}$ ). The fluorophore extracts, which reflect total Se, can be determined by fluorescence spectroscopy (emission at $560 \mathrm{~nm}$; excitation at $360 \mathrm{~nm}$ ) using 96 well microplates. Samples should be measured within a few hours of extraction. Concentrations of total Se in shark kidney samples obtained by the fluorometric assay were compared to values obtained using a conventional graphite furnace atomic absorption spectroscopy method as previously described [21]. The detection limit of total Se for the fluorometric assay ranged from 2 to $3 \mathrm{ng}$, with standard curve linearity for total Se concentrations up to $600 \mathrm{ng}$ (Figure 3).

\section{Results and Discussion}

Average recovery rates from the certified values of DOLT-3, TORT-2, and NIST $1566 \mathrm{~b}$ for total Hg were $98.9 \pm 4.3 \%(\mathrm{n}=61), 97.5 \pm 5.5 \%(\mathrm{n}=23)$, and $95.4 \pm$ $4.9 \%(n=3)$, respectively (Table 1$)$. For organic Hg, the average recovery rates from the certified values of DOLT-3, TORT-2, and NIST 1566b were $98.6 \pm 5.7 \%$ $(\mathrm{n}=47), 97.9 \pm 4.7 \%(\mathrm{n}=19)$, and $97.2 \pm 9.6 \%(\mathrm{n}=4)$, respectively (Table 1 ). For total $\mathrm{Hg}$ and organic $\mathrm{Hg}$, the relative standard deviation (RSD) was lower than $10 \%$ for all replicate measures. These results confirm the accuracy and precision of this method. The recoveries are similar to values published previously [4,20,21].

For total Se (Table 2), the recovery rates were within the certified values $( \pm 18 \%)$ for DOLT $-3(n=35 ; 103 \pm 18 \%)$, TORT-2 ( $\mathrm{n}=20 ; 99.2 \pm 15.7 \%)$, NIST 1568a $(\mathrm{n}=8 ; 102 \pm$ $16 \%)$, and NIST 1577b ( $\mathrm{n}=8 ; 97.3 \pm 11.7 \%)$. Total Se was not detected from apple leaves (NIST 1515;0.050 $\mu \mathrm{g} / \mathrm{g}$ ) which is likely due to the low concentration (close to detection limits) of Se in this material. Selenite (which is converted from all forms of Se) reacts with DAN to yield a fluorescent Se-DAN complex. The recovery rates of selenate standard stock solution (even at higher levels such as

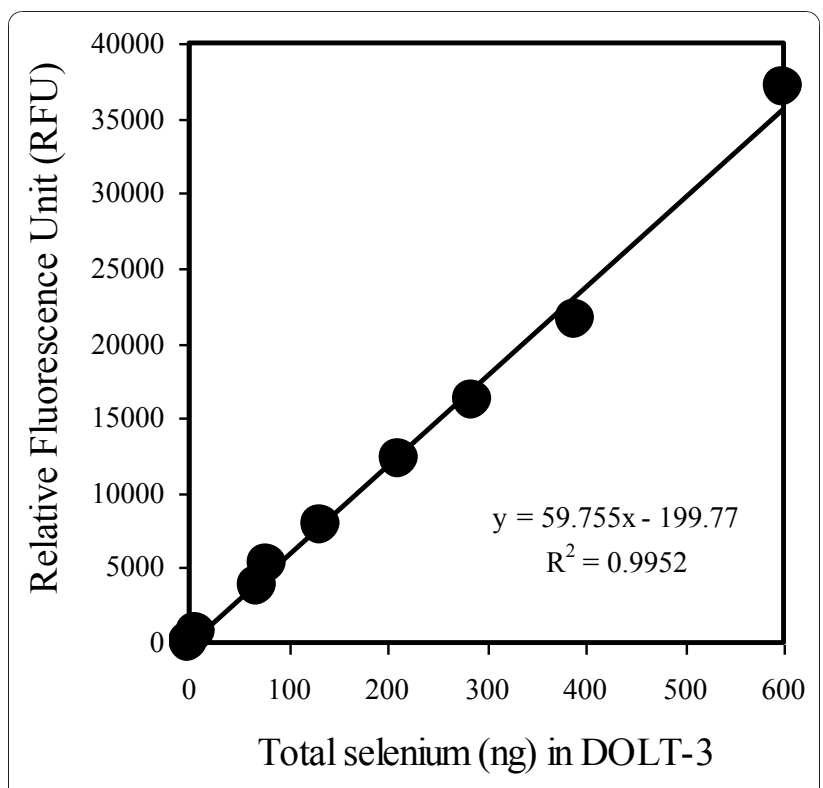

Figure 3 Relationship between predicted and measured total Se (ng) values in DOLT-3 using the fluorescence method described here. 
Table 1 Recovery rates of organic and total mercury concentrations in the certified reference materials

\begin{tabular}{|c|c|c|c|c|c|c|c|c|c|}
\hline \multicolumn{2}{|c|}{$\begin{array}{c}\text { Standard Reference Materials } \\
\text { (SRM) }\end{array}$} & \multicolumn{4}{|c|}{ Organic mercury ( $\mu \mathrm{g} / \mathrm{g}$ dry wt.)† } & \multicolumn{4}{|c|}{ Total mercury ( $\mu \mathrm{g} / \mathrm{g}$ dry $w \mathrm{t}.) \dagger$} \\
\hline & & $\begin{array}{l}\text { Expected } \\
\text { value }\end{array}$ & $\begin{array}{l}\text { Observed } \\
\text { value }\end{array}$ & $\mathbf{N}$ & $\begin{array}{l}\text { Recovery } \\
\text { (\%) }\end{array}$ & $\begin{array}{l}\text { Expected } \\
\text { value }\end{array}$ & $\begin{array}{l}\text { Observed } \\
\text { value }\end{array}$ & $\mathbf{N}$ & $\begin{array}{c}\text { Recovery } \\
\text { (\%) }\end{array}$ \\
\hline DOLT-3 & (Dogfish liver) & $1.59 \pm 0.12$ & $1.57 \pm 0.06$ & 47 & $98.6 \pm 5.7$ & $3.37 \pm 0.14$ & $3.33 \pm 0.15$ & 61 & $98.9 \pm 4.3$ \\
\hline TORT-2 & $\begin{array}{l}\text { (Lobster } \\
\text { hepatopancreas) }\end{array}$ & $0.152 \pm 0.013$ & $0.149 \pm 0.009$ & 19 & $97.9 \pm 4.7$ & $0.27 \pm 0.06$ & $0.26 \pm 0.02$ & 23 & $97.5 \pm 5.5$ \\
\hline $\begin{array}{l}\text { NIST } \\
1566 b\end{array}$ & (Oyster tissue) & $0.0132 \pm 0.007$ & $0.0128 \pm 0.0015$ & 4 & $97.2 \pm 9.6$ & $0.0371 \pm 0.0013$ & $0.0354 \pm 0.0022$ & 3 & $95.4 \pm 4.9$ \\
\hline
\end{tabular}

† Detection limit: $0.020 \mathrm{ng}$ by DMA-80.

Table 2 Recovery rates of total selenium in the certified reference materials

\begin{tabular}{llcccc}
\hline \multirow{2}{*}{ Standard Reference Materials (SRM) } & \multicolumn{3}{c}{ Total selenium $(\boldsymbol{\mu g} / \mathbf{g}) \dagger$} \\
\cline { 3 - 5 } & & Expected value & Observed value & N & Recovery (\%) \\
\hline DOLT-3 & (Dogfish liver) & $7.06 \pm 0.48$ & $7.27 \pm 1.09$ & 35 & $103 \pm 18$ \\
TORT-2 & (Lobster hepatopancreas) & $5.63 \pm 0.67$ & $5.58 \pm 0.77$ & 20 & $99.2 \pm 15.7$ \\
NIST 1568a & (Rice flour) & $0.38 \pm 0.04$ & $0.39 \pm 0.06$ & 8 & $102 \pm 16$ \\
NIST 1577b & (Bovine liver) & $0.73 \pm 0.06$ & $0.71 \pm 0.08$ & 8 & $97.3 \pm 11.7$ \\
NIST 1515 & (Apple leaves) & $0.050 \pm 0.009$ & ND & 4 & - \\
Selenite & (Standard stock solution) & 100 & 89.3 & 3 & 89.3 \\
& & 250 & 239 & 3 & 94.7 \\
Selenite & (Standard stock solution) & 100 & 86.2 & 4 & 86.2 \\
& & 250 & 229 & 3 & 91.6 \\
\hline
\end{tabular}

ND: Not detected, † Detection limit: 2 - 3 ng by fluorescence spectroscopy.

100 or $250 \mu \mathrm{g} / \mathrm{g})$ were similar to those from the selenite solution (Table 2). This indicates that the outline methodology is efficient at converting all selenate into selenite. In addition, Se concentrations in shark kidney samples ( $\mathrm{n}=$ 10) that were measured using the fluorometric method described here were comparable to those observed

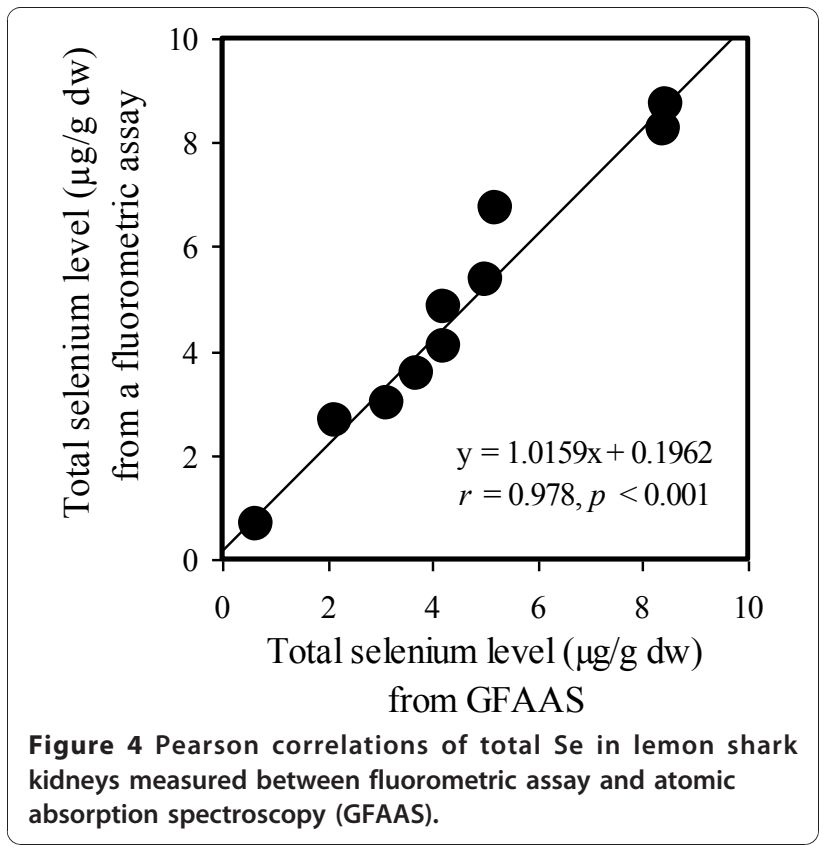

obtained using graphite furnace atomic absorption spectroscopy (GFAAS) method $(r=0.978 ; p<0.001)$ (Figure 4). Results of the current assay may provide a rapid and reliable analytical approach for measuring total Se, although the fluorophore stability results remained to be resolved.

\section{Conclusions}

Overall, the outlined approaches provide an easy, rapid ( $<1.5 \mathrm{hr}$ for organic $\mathrm{Hg},<5 \mathrm{~min}$ for total $\mathrm{Hg},<3 \mathrm{hr}$ for total Se), reproducible, and cost-effective platform for measuring organic $\mathrm{Hg}$ and total Se. As the methods are down-scaled, they require very small quantities of sample (10-50 mg) and can be performed on precious materials, and they generate less chemical waste than conventional approaches.

\section{Acknowledgements}

This work was funded by the University of Michigan School of Public Health. We thank Doug Adams (Florida Fish \& Wildlife Conservation Commission) for lemon shark tissues.

Authors' contributions

DN and NB designed the study, analyzed data, and drafted the manuscript. Both have read and approved the final manuscript.

\section{Competing interests}

The authors declare that they have no competing interests.

Received: 6 October 2010 Accepted: 13 January 2011

Published: 13 January 2011 


\section{References}

1. Clarkson TW, Magos L: The toxicology of mercury and its chemical compounds. Crit Rev Toxicol 2006, 36(8):609-662.

2. U.S. EPA: CERCLA Priority List of Hazardous Substances. 2007 [http://www. atsdr.cdc.gov/cercla/07list.html], [last accessed Jul 2, 2010].

3. U.S. EPA: National Listing of Fish Advisories. 2008 [http://www.epa.gov/ waterscience/fish/advisories/tech2008.html], [last accessed Jul 2, 2010].

4. Basu N, Scheuhammer A, Grochowina N, Klenavic K, Evans D, O'Brien M, Chan HM: Effects of mercury on neurochemical receptors in wild river otters (Lontra canadensis). Environ Sci Technol 2005, 39:3585-3591.

5. Basu N, Scheuhammer AM, Bursian SJ, Elliott J, Rouvinen-Watt K, Chan HM: Mink as a sentinel species in environmental health. Environ Res 2007, 103:130-44.

6. Aschner M, Aschner JL: Mercury neurotoxicity: mechanisms of bloodbrain barrier transport. Neurosci Biobehav Rev 1990, 14:169-176.

7. Castoldi AF, Coccini T, Ceccatelli S, Manzo L: Neurotoxicity and molecular effects of methylmercury. Brain Res Bull 2001, 55:197-203.

8. Jones RD, Jacobson ME, Jaffe R, West-Thomas J, Arfstrom C, Alli A: Method development and sample processing of water, soil, and tissue for the analysis of total and organic mercury by cold vapor atomic fluorescence spectrometry. Water Air Soil Poll 1995, 80:1285-1294.

9. Costley C, Mossop K, Dean J, Garden L, Marshall J, Carroll J: Determination of mercury in environmental and biological samples using pyrolysis atomic absorption spectrometry with gold amalgamation. Anal Chim Acta 2000, 405:179-183.

10. Valega M, Abreu S, Pato P, Rocha L, Gomes AR, Pereira ME, Duarte AC: Determination of organic mercury in biota, plants and contaminated sediments using a thermal atomic absorption spectrometry technique. Water Air Soil Poll 2006, 174:223-234.

11. Scheuhammer AM, Atchison CM, Wong AHK, Evers DC: Mercury exposure in breeding common loons (Gavia immer) in central Ontario, Canada. Environ Toxicol Chem 1998, 17:191-196.

12. Neugebauer EA, Sans Cartier GL, Wakeford BJ: Methods for the determination of metals in wildlife tissues using various atomic absorption spectrophotometry techniques. Technical Report Series 337. Canadian Wildlife Service, Hull, QC, Canada.; 2000.

13. Raymond $L$, Ralston NVC: Mercury:selenium interactions and health implications. Seychelles Medical and Dental Journal 2004, 7:72-77.

14. Khan MA, Wang F: Mercury-selenium compounds and their toxicological significance: toward a molecular understanding of the mercury-selenium antagonism. Environ Toxicol Chem 2009, 28:1567-1577.

15. Dietz R, Rigét FF, Born EW: An assessment of selenium to mercury in Greenland marine animals. Sci Total Environ 2000, 245:15-24.

16. Pedro J, Andrade F, Magni D, Tudino M, Bonivardi A: On-line submicellar enhanced fluorometric determination of Se (IV) with 2,3diaminonaphthalene. Anal Chim Acta 2004, 516:229-236.

17. Lott PF, Cukor P, Moriber G, Solga J: 2,3-diaminonaphthalene as a reagent for the determination of milligram to submicrogram amounts of selenium. Anal Chem 1963, 35:1159-1163.

18. Sheehan TM, Gao M: Simplified fluorometric assay of total selenium in plasma and urine. Clin Chem 1990, 36:2124-2126.

19. Johansson K, Luo X, Olin A: Rapid one-step derivatization of Se(VI) to a piazselenol for the spectrofluorimetric determination of selenium in biological material. Talanta 1995, 42:1979-1987.

20. Nam D-H, Adams DH, Flewelling LJ, Basu N: Neurochemical alterations in lemon shark (Negaprion brevirostris) brains in association with brevetoxin exposure. Aquat Toxicol 2010, 99(3):351-359.

21. Nam D-H, Adams DH, Reyier EA, Basu N: Mercury and selenium levels in lemon shark (Negaprion brevirostris) in relation to a harmful red tide event. Environ Monit Assess 2010.

doi:10.1186/1752-153X-5-3

Cite this article as: Nam and Basu: Rapid methods to detect organic mercury and total selenium in biological samples. Chemistry Central Journal 2011 5:3.

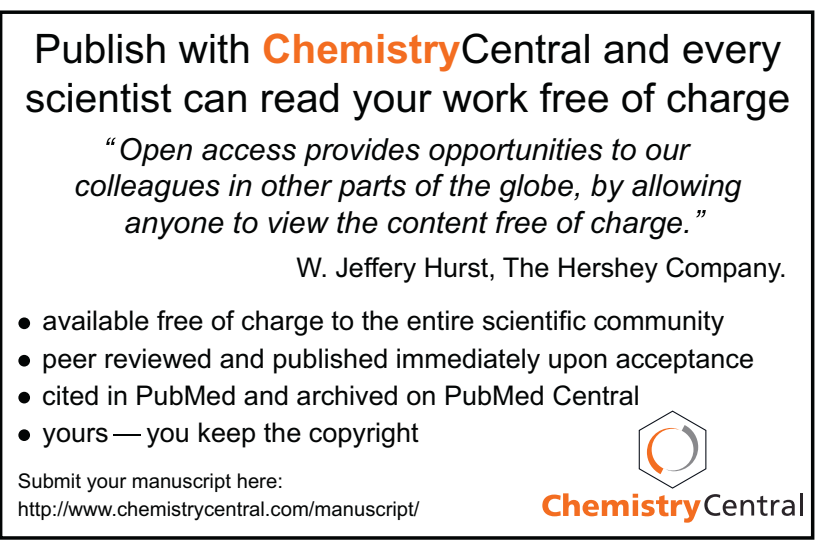

